\title{
Antithrombotic Therapy in Patients with Stroke An observational study
}

\author{
DAN IULIAN CUCIUREANU ${ }^{1}$, VICTOR ALEXANDRU CONSTANTINESCU ${ }^{1}$, CRISTIAN STATESCU ${ }^{2 *}$, RADU ANDY SASCAU2*, \\ DIANA NICOLETA HODOROG ${ }^{1}$, CRISTINA PREDA ${ }^{3}$, DELIA HINGANU 4 , MARIUS VALERIU HINGANU ${ }^{4}$, TUDOR CUCIUREANU 5 \\ ${ }^{1}$ Grigore T. Popa University of Medicine and Pharmacy,Faculty of Medicine, III-rd Medical Department, 16 Universitatii Str., \\ 700115, lasi, Romania \\ ${ }^{2}$ Grigore T. Popa University of Medicine and Pharmacy, Faculty of Medicine, 16 Universitatii Str., 700115, lasi, Romania \\ ${ }^{3}$ Grigore T. Popa University of Medicine and Pharmacy, Faculty of Medicine, II-nd Medical Department, 16 Universitatii Str., \\ 700115, lasi, Romania \\ ${ }^{4}$ Grigore T. Popa University of Medicine and Pharmacy, Faculty of Medicine, I-st Morpho-Functional Sciences Department, 16 \\ Universitatii Str., 700115, Iasi, Romania \\ ${ }^{5}$ Grigore T. Popa University of Medicine and Pharmacy, Faculty of Medicine, I-st Medical Department, 16 Universitatii Str., 700115 , \\ lasi, Romania
}

\begin{abstract}
Cerebrovascular disease is the second leading cause of death in developed countries after cardiovascular disease, with a prevalence of 794 percent of hundred thousand of people. Ischemic stroke (IS) remains an important public health issue of great importance in terms of its reality and the morbidity it implies, although the tendency is to reduce epidemiological indicators. In this paper we have updated informations on etiopathogenesis, epidemiology, pathological anatomy, clinical, laboratory and imaging investigations, differential diagnosis, evolution, complications, prophylaxis with antiplatelet treatment of patients with IS. IS remains an important public health issue of great importance in terms of its reality and the morbidity it implies, although the tendency is to reduce epidemiological indicators. Platelet function testing may potentially be useful in monitoring the biological effect of platelet antiaggregant medication. Aggregometry could provide personalized prognostic information and may thus become a useful tool in designing strategies for prevention and management of ischemic stroke.
\end{abstract}

Keywords: ischemic stroke, antiplatelet treatment, cerebrovascular disease

Strokes have an increasing percentage among young population, are of extreme gravity and have serious psychological and social consequences. For these reasons, we considered it useful to evaluate the risk factors, epidemiology data, onset disease data, evolution and treatment methods in order to complete the diagnosis and prevention methods of this disease.

The increased incidence of this pathology is correlated with the decreasing in onset age of the disease.

Cerebrovascular disease is the second leading cause of death in developed countries after cardiovascular, with a prevalence of 794 percent of hundred thousand of people. Mortality is $70 \%$ and loss of workforce patients as well as extension of hospitalization creates an important economic impact [1].

The incidence of IS is higher in economically developed countries, increases with age, and predominates in males at a rate of 1.3 compared to women. Unfortunately, the possibilities of treatment in IS are not commensurated with the advances made in its pathophysiological knowledge.

Cerebrovascular diseases has as a starting point a cumulus of risk factors such as hypertension, dyslipidemic syndrome, diabetes, obesity. In many patients with atrial fibrillation a stroke occurs as the first clinical manifestation. Thus, in these patients, pulse rate variability parameters can predict cerebrovascular events [2-6].

Atrial fibrillation is a serious health problem because it can lead to important complications for stroke. Management of this arrhythmia should include not only its treatment but also antithrombotic therapy $[7,8]$. All these aspects are more serious as there is a large proportion of cases of undiagnosed atrial fibrillation and untreated with oral anticoagulants [9-12].

Stroke generates about $10 \%$ of new cases of epilepsy and $55 \%$ of newly diagnosed cases in elderly pacients. In the literature there is a consecutive increase in the prevalence of epilepsy related to stroke. Epilepsy may begin early (in the first 7 days from stroke onset) or may appear later convulsions (after more than 7 days).

Early onset of epilepsy after IS (STRE) is considered to be the consequence of local metabolic disorders without alterations of other neural networks, and the latter onset of epilepsy occurs when the brain has a predisposition for convulsions.

The occurrence of IS after epilepsy maylead to increased morbidity, longer hospitalization and greater disability. Further controlled trials are needed to explore the primary and secondary STRE prevention as well as to provide new proofs on the efficacy and tolerability of anti-epileptic drugs in order to guide STRE treatment. Preclinical and clinical STRE predictive models are also required to develop treatments in order to prevent transformation of the devascularized tissue into an epileptic source.

The diagnosis of stroke and/or epilepsy after stroke is confirmed by MRI. This will show a series of abnormalities that can be missed by CT examination, such as cortical malformations, hippocampal sclerosis and cavernomas [13-15].

The treatment of IS consists of that of the underlying disease but also of its secondary effects. After CT and MRI exclusion of non-thromboembolic haemorrhage, anticoagulation therapy is practiced. Thus, in acute transientcerebral ischaemia (TIS) ithas prophylactic value

* email: cstatescu@gmail.com; radusascau@gmail.com 
(the risk of stroke after an TIS is 24-29\%). Anticoagulants are also recommended in: case of significant arterial stenosis, especially in vertebro-basilar territory, in patients with transient cerebral ischemia of cardioembolic origin, in progressive stroke as an expression of atheromatic plaque instability, but only if the lesion area detected by CT is small.

Randomized clinical trials [16-20] highlights the benefits of anticoagulant therapy in stroke patients, meaning that anticoagulant drugs prophylaxise the progression of neurological deficit. This is a different approach to the protocols used at the moment. Anticoagulant indications in stroke with a defined embolic cause is to be administered after $48 \mathrm{~h}$. It only applies in the case of cardiac metal valves, due to the high risk of clogging.

In this paper we have updated informations on etiopathogenesis, epidemiology, pathological anatomy, clinical, laboratory and imaging investigations, differential diagnosis, evolution, complications, prophylaxis with antiplatelet treatment of patients with ischemic strokes (IS). IS remains an important public health issue of great importance in terms of its reality and the morbidity itimplies, although the tendency is to reduce epidemiological indicators

\section{Experimental part}

The study is conducted on a group of 165 patients aged between 25 and 50 years admitted to the I Neurology Clinic of Prof. Dr. Nicolae Oblu Emergency Clinical Hospital in lasi, berween 2014-2018 period, diagnosed with different forms of IS.

The 165 cases were analyzed taking into account all aspects of anamnesis and etiopathogenesis, suggested by the clinical examination and revealed by the laboratory exams.

The examination was performed according to the clinic protocol and special attention was paid to the ophthalmologic, cardiological, clinical, ECG, IRM and ECHO Doppler vascular examinations. Depending on the particularity of the clinically explored cases, it were performed:

-research of current biological samples regarding the proteic, lipidic, carbohydrate, hydroelectrolytic and acidobasic balance;

-research of immunological samples, CIC, Latex, WallerRose, immunoglobulins;

-research of bacteriological, haemocultures, urocultures samples in infectious complication;

-cerebrospinal fluid (CSF) examination - cytology, biochemistry, serology;

-EEG, ECG, CT, Angiography, Echo Dopler, as appropriate.

The results obtained were discussed and compared with those in the literature.

\section{Results and discussions}

All patients were aged between 25 and 50 years. The distribution on age and gender criteria is found in tables 1 and 2.

The treatmentobjectives in these patients are restoration of cerebral circulation and provision of a cerebral vascular flow adequate to metabolic and cellular needs. This has been done in patients with thromboembolic etiopathogenesis at the macrovascular level in order to reopen the blood vessel, prevent the propagation and prophylaxis of recurrences.

The restoration of hemodynamic homeostasis aimed correction of systemic hypotension and restoration of cerebral perfusion pressure.

\begin{tabular}{|l|l|l|}
\hline Age & $\begin{array}{l}\text { Ischemic } \\
\text { stroke cases }\end{array}$ & Percent \\
\hline $25-30$ & 7 & $4 \%$ \\
\hline $31-35$ & 10 & $6 \%$ \\
\hline $36-40$ & 23 & $14 \%$ \\
\hline $41-45$ & 49 & $30 \%$ \\
\hline $46-50$ & 76 & $46 \%$ \\
\hline
\end{tabular}

\begin{tabular}{|l|l|l|}
\hline Gender & Number & Percent \\
\hline Male & 95 & $58 \%$ \\
\hline Female & 70 & $42 \%$ \\
\hline Total & 165 & $100 \%$ \\
\hline
\end{tabular}

\section{Table 3}

THE CLINICAL EVOLUTIVE FORMS OF IS AND THE AFFECTED VASCULAR TERRITORY. RIS - RECURRENT ISCHEMIC STROKE; CIS -CONSTITUTED ISCHEMIC STROKE; PIS- PROGRESSIVE ISCHEMIC STROKE

\begin{tabular}{|l|l|l|l|l|}
\hline & $\begin{array}{l}\text { Carotidid } \\
\text { level }\end{array}$ & $\begin{array}{l}\text { Sylvian } \\
\text { level }\end{array}$ & $\begin{array}{l}\text { Vertebrobasilar } \\
\text { level }\end{array}$ & Total \\
\hline TIS & 22 & 14 & 18 & 66 \\
\hline RIS & 14 & 26 & 5 & 56 \\
\hline CIS+PIS & 11 & 21 & 9 & 55 \\
\hline Total & 47 & 61 & 32 & 165 \\
\hline
\end{tabular}

The classification of patients according to their demographic origin shows that $54 \%$ are from the urban area and the rest from rural areas.

It can be observed an increased frequency of IS in the Carotid territory than in the vertebrobasilar one.

TIS had a more significant percent in the total IS, the frequency being approximately equal in both carotid and vertebrobasilar level (table3).

As a clinical manifestation, hemiparesis is the dominant syndrome of an IS. Located on the right in one quarter of the cases, it is accompanied by aphasia (table 4).

Table 4

CLINICAL SYMTOMS

\begin{tabular}{|l|l|l|}
\hline Hemiparesis & 84 & $84 \%$ \\
\hline Aphazia & 41 & $41 \%$ \\
\hline Seizures & 9 & $9 \%$ \\
\hline Affecting the consciousness & 10 & $10 \%$ \\
\hline Hemianopsia & 2 & $2 \%$ \\
\hline $\begin{array}{l}\text { Bulbare syndrom+ pontin } \\
\text { syndrom }\end{array}$ & 6 & $6 \%$ \\
\hline Wallenberg syndrom & 6 & $6 \%$ \\
\hline Weber syndrom & 1 & $1 \%$ \\
\hline Millard- gubler syndrom & 1 & $1 \%$ \\
\hline
\end{tabular}

There is a higher frequency of IS in carotid territory than in the vertebrobasilar. Thromboembolic occlusions are more frequent in the carotid and vertebral arteries: thrombotic occlusions are more common in the carotid artery while embolic occlusions are more common in the vertebral artery (table 5).

In order to achieve these goals, treatment has been established with thrombolysis, surgical revascularization, anticoagulants, platelet antiaggregant, colloidal plasma substitutes.

Most commonly, the field on which IS is produced is the hypertensive dyslipidemic one. Cardiac disorders (valvular, chronic ischemic cardiopathy) are favorable conditions for IS. Specification of an associated diagnosis (risk factor) is less common compared to literature data (table 6).

Under anti-coagulant and platelet antiaggregant treatment, most patients left the hospital in improved condition, with a relatively low number of deaths (table 7).

At the microcirculation level, it was considered to eliminate vasoconstriction and cell edema by administering 


\begin{tabular}{|l|l|l|l|}
\hline & $\begin{array}{l}\text { Thromboembolic (arterio- } \\
\text { arterial embolism) }\end{array}$ & thrombosis & embolism \\
\hline Carotid artery & 25 & 19 & 11 \\
\hline $\begin{array}{l}\text { Medial } \\
\text { cerebral artery }\end{array}$ & 12 & 9 & 7 \\
\hline $\begin{array}{l}\text { Anterior } \\
\text { cerebral artery }\end{array}$ & 6 & 5 & 4 \\
\hline $\begin{array}{l}\text { Posterior } \\
\text { cerebral artery }\end{array}$ & 16 & 10 & 11 \\
\hline $\begin{array}{l}\text { Vertebral } \\
\text { artery+ basilar } \\
\text { trunk }\end{array}$ & 22 & 12 & 16 \\
\hline
\end{tabular}

Table 5

ETIOLOGIC MECHANISM (THROMBOSIS, EMBOLISM) AND IS LOCATION
Table 6

ETIOLOGY - FREQUENCY OF ETIOLOGICAL FACTORS

\begin{tabular}{|l|l|l|}
\hline Arterial hypertension & 58 & $32.58 \%$ \\
\hline Atrial Fibrillation & 27 & $15.17 \%$ \\
\hline Valvular disorders & 23 & $12.9 \%$ \\
\hline $\begin{array}{l}\text { Chronic ischemic } \\
\text { cardiopathy }\end{array}$ & 26 & $14.6 \%$ \\
\hline Dyslipidemia & 36 & $20.22 \%$ \\
\hline Obesity & 34 & $19.10 \%$ \\
\hline $\begin{array}{l}\text { Cerebral } \\
\text { atherosclerosis }\end{array}$ & 30 & $16.85 \%$ \\
\hline $\begin{array}{l}\text { Obliterant arteriopathy } \\
\text { of lower limbs }\end{array}$ & 13 & $7.30 \%$ \\
\hline Diabetes & 17 & $9.55 \%$ \\
\hline
\end{tabular}

Table 7

PATIENTS CONDITION AT DISCHARGE

\begin{tabular}{|l|l|l|}
\hline Improved & 141 & $86 \%$ \\
\hline Stationary or aggravated & 19 & $12 \%$ \\
\hline Deceased & 5 & $2 \%$ \\
\hline
\end{tabular}

calcium antagonists, magnesium, $5 \mathrm{HT}$ receptor blockers and hemodilution.

All patients with embolic sourse received after $48 \mathrm{~h}$ heparin therapy which acts as antithrombin, antiprotrombin, antithromboplastin inhibition of platelet adhesion, prolonging coagulation time but without modifying bleeding time parameter. It was administered as follows:

-initial intravenous bolus of 5000-10000 u followed by continuous heparin perfusion at a rate of 100-1500-2000 $\mathrm{u} / \mathrm{h}$ with automatic syringe. It is recommended when there is evidence that the thrombus has formed.

-subcutaneous in small but sufficient doses for activation of AT III and for prevention of coagulation at doses of 500$800 \mathrm{u}$ heparin followed by repeated intravenous bolus of 5000-10000 u heparin at $4 \mathrm{~h}$. Intravenous continue perfusion were preferred instead of intermittent administrations.

The Intravenous heparin bolus that preceed perfusion is necessary, so the hypocoagulability is only achieved approximately $6 \mathrm{~h}$ after the perfusion. In the case of continuous heparin perfusions, test blood control is performed once a day, with the recommendation thatblood coagulability test to be done as close as possible to blood collection, in order to prevent neutralization of the anticoagulant effect by platelet factor 4 mobilized from endothelial deposits by heparin.

Blood testing involves the determination of partially activated thromboplastin time (TTPA), which under heparin therapy should reach 1.5-2.5 higher.

If continuous heparin perfusion is used, the coagulation tests will be necessary approximately 4 hours after the intravenous bolus injection.

Coumarin agents inhibit vitamin K-dependent coagulation factors resulting in inactive biological forms. They are orally administered and indicated for long-term treatment.
There are two types of coumarin agents, depending on the plasmatic half-life and the duration of action:

Biohydroxycoumarin - a half-life of 2 to $3 \mathrm{~h}$ and a duration of action of 24 to $48 \mathrm{~h}$. The average dose is $75 \mathrm{mg}$ per day.

Warfarin has a half-life of approximately 45 hours and a duration of action of 90 to $120 \mathrm{~h}$. The average maintenance dose is $2-15 \mathrm{mg}$ per day.

In medical practice, Phenprocumon is used more frequently, the duration of action can be $240 \mathrm{~h}$. The thrombostop ( $2 \mathrm{mg} /$ tablet) with a half-life of $8 \mathrm{~h}$ and a duration of action ranging from 48 to $96 \mathrm{~h}$ is also part of the acenocumarol group.

Nowadays we use for long time prophylaxy NOAC (non vitK anticoagulant compound), direct factor Xa inhibitors (apixaban, rivaroxaban), direct thrombin inhibitors (dabigatran ) after 3-14 days depending o the severity of stroke.

The evolution of this pathology is related to the type of the ischemic stroke:

-The TIS is short-lived from a few seconds and minutes in hours (not exceeding $1 \mathrm{~h}$ ), it is characteristic that it can usually relapse in the same territory and it ends with a major stroke (infarction or haemorrhage) beeing a signal alarm:

-Progressive stroke regresses after 2-3 weeks, sometimes the patient is completely recovered.

It should be noted that 17 of these patients developed epilepsy seizures in the next two years.

Complete ischemic stroke can lead to exitus within the first 4 weeks, depending on evolution (13-42\%) with more in the first 3-10 days.

In order to establish a prognosis, it should be considered the existence of associated risk factors: hypertension, cardiac disease, myocardial infarction, lung infections, leading to exitus after cerebral ischemic stroke.

Recurrence are possible in the first 5 years (25\%). During this period it occurs some disturbances as well as the high degree of physical instability which may also favor the establishment of the exitus. Strokes of the brainstem and those with bilateral lesions have a more limited prognosis.

Of the patients who survived the stroke, most of them have a hemiplegic motor deficit that passes after 3-8 weeks, from the flaccid phase to the spastic phase. At first movements reappear in larger joints, especially the lower limbs, which gives to patient possibility to move.

In relation to the remaining sequelae which gives the patient a reduction or a total loss of self-care, social reintegration and work capacity, the sickness can fall into four categories (scales- Barthel scale):

-total independence, total resumption of socialprofessional life;

-a reducing of professional activity, but patient can serve themselves;

-pronounced dependence with considerable reduction of professional activity;

-total dependence on all activities. 
The risk of cerebral infarction after the TIS is between $6-9 \%$ in the first months and $5 \%$ per year over the next 3 years $[19,20]$.

The main risk of heparin treatment is systemic and intracerebral haemorrhage. This side effect can be neutralized in minutes by intravenous administering of protamine sulphate $2 \mathrm{mg}$ per $\mathrm{ml}$ solution, slowly, not more than $50 \mathrm{mg}$ in $10 \mathrm{~min}$.

Other major side effects are: cephalalgia, circulatory disturbances, allergic reactions, bone pain, severe thrombocytopenia.

Other frequently used antiaggregants are aspirin, clopidogrel and triflusal.

In the usual medical practice, measurement of platelet reactivity in patients with stroke treated with platelet antiaggregants is nota routine maneuver. Through our study we evaluated the response to the mentioned patients' therapies and compared them with the literature.

The response to aspirin was significantly better in combination with one of the two drugs used in this study and vice versa. Also, the combination of anticoagulant medication with a clopidogrel-type anti-aggregate potentiates the patient's response to treatment and improves the post-stroke hematoencephalic barrier activity in patient with severe heart disease [21, 22].

The occurrence of a recurrent stroke during treatment with antiplatelet agents has a therapeutic dilemma. One of the main causes is platelet resistance more commonly known as high on-treatment platelet reactivity (HTPR). Previous studies have established that proteinuria is associated with HTPR after myocardial infarction. Thus, proteinuria is an independent predictor of HTPR, but after risk factors such as older age, smoking, diabetes, hypertension. Platelet resistance is a genetic clinical entity that compromises the effectiveness of treatment with antityrombotics and, especially with platelet antiaggregants [23, 24].

In order to prevent and treat in due course such situations, it is necessary to perform radiological monitoring of patients, especially MRI and/or angiography [25-27], and a complete clinical balance. The discovery of an associated pathology can radically change the therapeutic protocol [28-30].

Specialty literature shows that more than a third of patients with ischemic stroke caused by occlusion of large intracranial vessels do not recover their functional independence, despite of rapid and successful recanalization by acute mechanical thrombectomy. Platelet antiaggregants and heparin may restore microvascular reperfusion but may also increase the risk of symptomatic intracranial haemorrhage. Some studies indicate a slight increase in the risk of symptomatic intracranial haemorrhage, acceptable in the context of a beneficial effect on functional outcomes [31, 32].

\section{Conclusions}

Platelet function testing may potentially be useful in monitoring the biological effect of platelet antiaggregant medication. Aggregometry could provide personalized prognostic information and may thus become a useful tool in designing strategies for prevention and management of ischemic stroke. Thorough studies are needed to answer the question whether the potentially greater risk of symptomatic intracranial haemorrhage that is given by this type of medication, might be compensated by improved functional results.

\section{References}

1.PIFFER, S., BIGNAMINI, V., ROZZANIGO, U. etal. , 27, no.12, 2018, p. 3578.

2.SLUYTER, J.D., CAMARGO, C.A., LOWE, A., SCRAGG, R.K.R., International Journal of Cardiology, 275, 2019, p. 83.

3.DAVISON, W.J., MYINT, P., KYAW, C., ALLAN, B. et al., 207, 2019, p. 58.

4.BOANGHER, S., MESPOUILLE, P., GOFFETTE, S., VAN PESCH, V., CUCIUREANU, D. Herpes simplex encephalitis relapse associated with positive $\mathrm{N}$-methyl-d-aspartate receptor antibodies. Acta Neurologica Belgica, 118, no.4, 2018; p. 533.

5.CUCIUREANU, D.I., STATESCU, C., SASCAU, R.A., CUCIUREANU, T., CONSTANTINESCU, V.A., HINGANU, D., PREDA, C., HINGANU, M.V., TURLIUC, M.D. Particularities of using contrast agents in diagnosis of stroke. Rev Chim (Bucharest), 70, no.2, 2019, p. 685-688.

6.CONSTANTINESCU, V., MATEI, D., COSTACHE, V., CUCIUREANU, D., ARSENESCU-GEORGESCU C., NEUROLOGIA I NEUROCHIRURGIA POLSKA, 52, no.2, 2018, p.194.

7.SALARU, D.L., MACOVEI, L., STATESCU, C., ARSENESCUGEORGESCU, C., Assessment of microalbuminuria in hypertensive patients with established coronary artery disease. REVISTA ROMANA DE MEDICINA DE LABORATOR, 21, no.4, 2013, p. 407. DOI: 10.2478/ rrIm-2013-0041

8.VASILCU, T.F., STATESCU, C., SASCAU, R., ROCA, M., COSTEA, C.F., ZOTA, M., BARARU, I., CONSTANTIN, M.L., MITU, F, Rev. Chim. (Bucharest), 69, no.8, 2018, p. 2283

9.CUCIUREANU, D.I., CUCIUREANU, T., CUCIUREANU, A., Neurotic disorder and unexpected EEG records in apparent healthy people. [abstract no. p935]. Journal of the Neurological Sciences. 2017; 381 (suppl S): 339.

10.CUCIUREANU DI, NITA A, CUCIUREANU A, CUCIUREANU T, CONSTANTINESCU IM. Experience with first episode of consciousness loss assessment in a regional center of Romania. [abstract no. p638]. Epilepsia. 2016; 57 (suppl. 2): 194.

11.AFABE STUDY, Prevalence of Undiagnosed Atrial Fibrillation and of That Not Being Treated With Anticoagulant Drugs.. Revista Espanola de Cardiologia 2013: 66; 7: 545-552.

12.*** Guidelines for the management of atrial fibrillation, The Task Force for the Management of Atrial Fibrillation of the European Society of Cardiology (ESC). European Assoc Cardio-Thoracic. European Heart Journal 2010: 31/19: 2369-2429.

13.ROBERTS R. What investigations should be performed on adults? J R Coll Physicians Edinb 20033339-40.

14.MINDRUTA, I.R., BAJ ENARU, O.A., PANEA, C.A., et al. Experience with lacosamide in treating focal epilepsy patients in Romania: efficacy, safety and time to reach response [abstract no. p332]. Epilepsia. 2014; 55(Suppl 2):110.

15.CUCIUREANU DI, CONSTANTINESCU IM, DANCIU F, CUCIUREANU T. Brain tuberculomas revealed by epileptic generalized seizures after tuberculostatic treatment: a case report. [abstract no. p0516]. Epilepsia; 2015; 56(suppl. 1): 128.

16.SHAHPOURI, M.M., MOUSAVI, S., KHORVASH, F., MOUSAVI, S.M., HOSEINI, T., J Res Med Sci. 17, no.4, 2012, p. 396.

17.SHAH, S.J ., ECKMAN, M.H., ASPBERG, S., GO, A.S., SINGER, D.E., Ann Intern Med., 169, no. 8, 2018, p. 517.

18.HAKMA, Z., STOFKO, D.L., BINNING, M.J., LIEBMAN, K., VEZNEDAROGLU, E., Surg Neurol Int., 6, 2014, p62.

19.GOLDSTEIN, L.B., Methodist Debakey Cardiovasc J., 10, no.2, 2014, p.99.

20.SALARU, D.L., MACOVEI, L., STATESCU, C., ARSENESCUGEORGESCU, C. Rev ROMANA Med Lab, 21, no.4, 2013, p. 407-414.

21.*** Steering Comm Investigators. Five-Year Risk of Stroke after TIA or Minor Ischemic Stroke Reply. New England J ournal of Medicine. 2018; 379/16: 1580-1581

22.ROSAFIO, F., LELLI, N., MIMMI, S., VANDELLI, L., BIGLIARDI, G., DELL'ACQUA, M.L., PICCHETTO, L., PENTORE, R., FERRARO, D., TRENTI, T., NICHELLI, P., ZINI, A., J Stroke Cerebrovasc Dis., 26, no.8, 2017, p. 1864. 
23.GEORGE, G., PATEL, N., JANG, C., WHEELER, D., YADDANAPUDI, S.S., DISSIN, J., BALU, R., RANGASWAMI, J.M., Proteinuria Predicts Resistance to Antiplatelet Therapy in Ischemic Stroke. Translational Stroke Research, 9, no.2, 2018, p. 130.

24.HINGANU, D., SCUTARIU, M.M., HINGANU, M.V., Annals of AnatomyAnatomischer Anzeiger, 218, 2018, p. 271.

25.RUSU, A.R.G., TARTAU, L.M., STATESCU, C., BOANCA, M., POROCH, V., LUPUSORU, R.V., DIMA, N., BADESCU, C., REZUS, E., REZUS, C., LUPUSORU, C.E. Rev Chim (Bucharest), 69, no.6, 2018, p. 1493-1497 26.HINGANU, D., HINGANU, M.V., MIHALCEANU, E., CALIN, A.M., PANGAL, A., COSTACHESCU, G., ROMILA, A., Rev Chim (Bucharest), 69, no. 2, 2018, p. 714.

27.VASILCU, T.F., STATESCU, C., SASCAU, R., ROCA, M., COSTEA, C.F., ZOTA, M., BARARU, I., CONSTANTIN, M.L., MITU, F. Rev Chim (Bucharest), 69, no.8, 2018, p. 2283-2286.
28.HINGANU, M.V., HINGANU, D., COZMA, S.R., ASIMIONOAIEISIMIONESCU, C., SCUTARIU, I.A., IONESIE, D.S., HABA, D., Annals of Anatomy, 220, 2018, p. 1.

29.RUSU, A.R.G., TARTAU, L.M., STATESCU, C., BOANCA, M., POROCH, V., LUPUSORU, R.V., DIMA, N., BADESCU, C., REZUS, E., REZUS, C., LUPUSORU, C.E., Rev Chim (Bucharest), 69, no.6, 2018, p. 1493. 30.VAN DE GRAAF, R.A., CHALOS, V., DEL ZOPPO, G.J., VAN DER LUGT, A., DIPPEL, D.W.J ., ROOZENBEEK, B., Front Neurol., 16, no.9, 2018,p. 238.

31.HINGANU MV, SALAHORU P, HINGANU D. Rev Med Chir Soc Med Nat lasi, 122, no.3, 2018, p. 522.

32.NESSELROTH, D., GILAD, R., NAMNEH, M., AVISHAY, S., EILAM, A., Seizure, 62, 2018, 91.

Manuscript received: 23.11.2018 